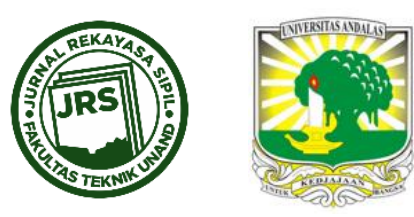

\title{
ANALISIS SPASIAL KEKERINGAN METEOROLOGIS DAERAH ALIRAN SUNGAI SIAK
}

\author{
MANYUK FAUZI ${ }^{1}$, BAMBANG SUDJATMOKO ${ }^{2}$, SUPRASMAN $^{2}$, \\ IMAM SUPRAYOGI ${ }^{2}$, SANDI CAHYONO ${ }^{2}$ \\ ${ }^{1}$ Teknik Sipil, Fakultas Teknik, Universitas Riau,Pekanbaru(凹manyuk.fauzi@unri.ac.id) \\ ${ }^{2}$ Jurusan Teknik Sipil, Fakultas Teknik, Universitas Riau, Pekanbaru \\ Naskah diterima : 5 September 2017. Disetujui: 10 Oktober 2017. Diterbitkan : 22 Oktober 2017
}

\begin{abstract}
ABSTRAK
Daerah aliran sungai Siak bagian hilir merupakan kawasann gambut yang luas dengan kategori gambut sangat dalam (lebih dari 4 meter). Hingga Agutus 2017, berdasarkan laporan Jaringan Kerja Penyelamat Hutan Riau (Jikalahari) jumlah hotspot pada lahan gambut di Provinsi Riau dengan kedalaman lebih dari 4 meter mencapai 397 titik. Kebakaran hutan dan lahan gambut merupakan agenda tahunan Riau, khususnya pada musim kemarau (kering). Tingkat kekeringan suatu daerah dapat diketahui dengan menghitung indeks kekeringannya. Indeks kekeringan merupakan suatu perangkat utama guna mendeteksi, memantau dan mengevaluasi kejadian kekeringan. Salah satu metode guna menghitung indeks kekeringan adalah metode Thornthwaite Mather. Metode tersebut menekankan pentingnya faktor curah hujan dan evapotranspirasi potensial. Analisis kekeringan dilakukan berdasarkan data hujan yang terukur dan tercatat pada 4 stasiun di dalam daerah aliran sungai Siak meliputi Buatan, Kandis, Petapahan Baru dan Pekanbaru. Hasil analisis menunjukan nilai total maksimum indeks kekeringan terjadi pada tahun 2014 dan Tahun 2015 dengan persentase sebagai berikut stasiun hujan Buatan 466,31\%, Kandis 398,33\%, Petapahan Baru 757,17\% dan Pekanbaru 520,77\%.
\end{abstract}

Kata kunci : indeks kekeringan, daerah aliran sungai siak, thornthwaite mather

\section{PENDAHULUAN}

Peraturan Menteri Pekerjaan Umum dan Perumahan Rakyat (PUPR) Nomor 04/PRT/M/2015 menetapkan wilayah sungai Siak sebagai Sungai strategis Nasional. Secara teknis sungai Siak memiliki palung sungai terdalam di Indonesia, dengan kedalaman sekitar 20-30 m. Wilayah sungai Siak keseluruhannya berada di wilayah administrasi Provinsi Riau. Berdasarkan laporan dari Kementerian PUPR pada tahun 2005 sungai Siak masuk kedalam kategori kritis, kawasan rawan bencana banjir, kekeringan, longsor, terjadi berbagai pencemaran, erosi dan pendangkalan.

Wilayah sungai Siak di bagian hilirnya merupakan lahan gambut yang luas dan masuk kedalam kategori gambut dalam dimana kedalaman gambut lebih dari 4 meter (lihat Gambar 1). Laporan Jaringan Kerja Penyelamat Hutan Riau menampilkan jumlah titik panas (hotspot) di Tahun 2017 hingga bulan Agustus menyebutkan bahwa jumlah hotspot 
pada gambut dengan kedalaman lebih dari 4 meter mencapai 397 titik. Jumlah hotspot tersebut merupakan yang terbesar dibandingkan dengan kedalaman gambut yang kurang dari 4 meter serta tanah mineral.

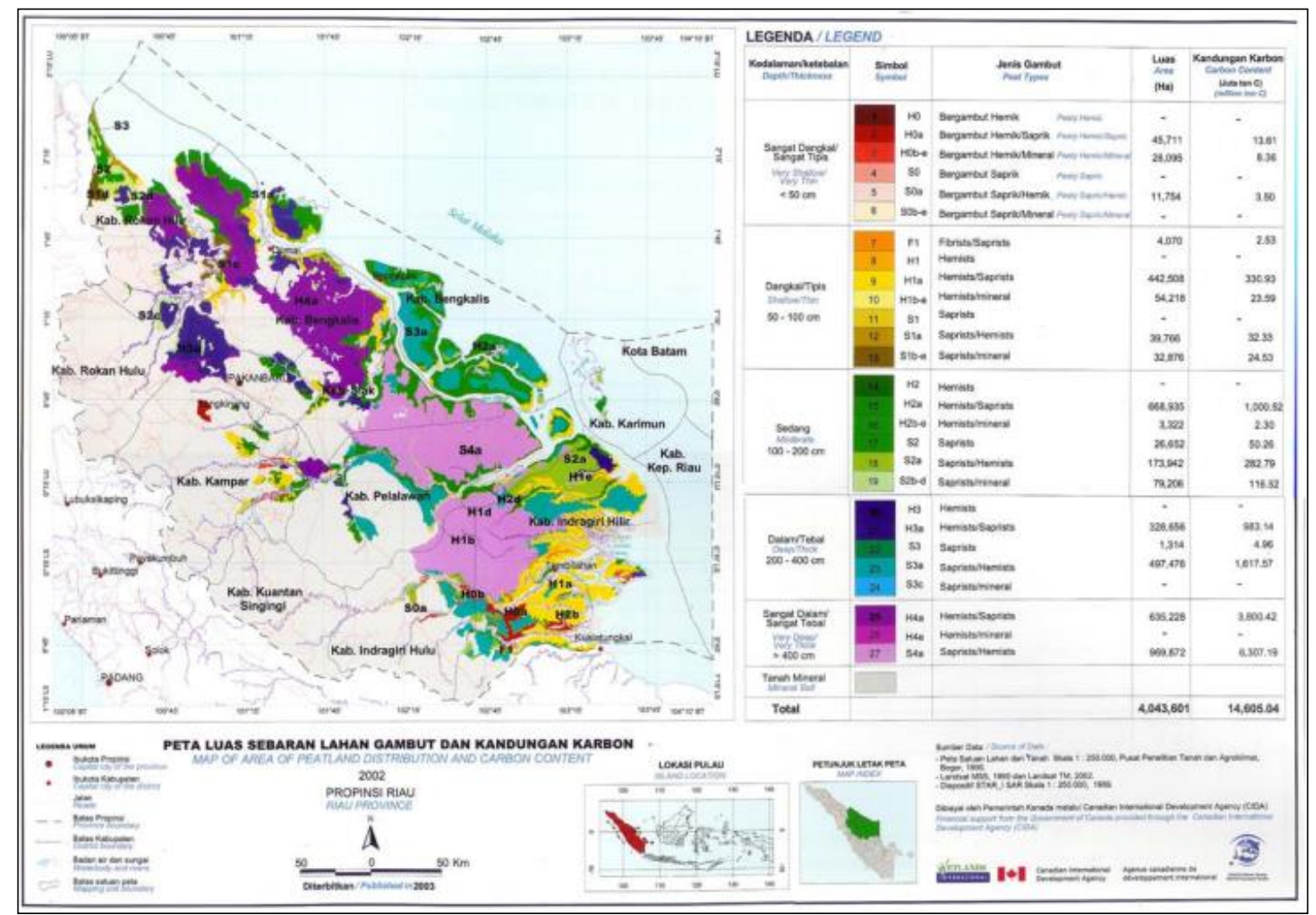

Gambar 1. Peta Luas Sebaran Lahan Gambut dan Kandungan Karbon di Provinsi Riau

Sebagimana dipaparkan sebelumnya bahwa kategori kritis sungai Siak salah satu penyebabnya adalah kekeringan. Kekeringan adalah ketersediaan air yang jauh di bawah kebutuhan air untuk kebutuhan hidup, pertanian, kegiatan ekonomi, dan lingkungan (BNPB, 2012). Kejadian kekeringan terjadi hampir seluruh dunia akibat jarangnya air serta adanya musim kemarau yang berkepanjangan akibat penyimpangan iklim seperti El Nino. Masalah kekeringan menjadi hal rutin yang terjadi di Indonesia, tetapi penanganan untuk pencegahan dan penanggulangan sangat lamban sehingga menjadi masalah berkepanjangan yang tidak terselesaikan (Ersyidarfia, 2012). Tingkat kekeringan suatu daerah dapat diketahui dengan menghitung indeks kekeringannya. Indeks kekeringan merupakan suatu perangkat utama untuk mendeteksi, memantau, dan mengevaluasi kejadian kekeringan. Beberapa penelitian yang telah berhasil menganalisis indeks kekeringan pada daerah aliran sungai menggunakan metode Thornthwaite Mather, diantaranya penelitian yang dilakukan oleh Sholikhati (2013), Jauhari (2015), dan Kafindo (2015). Penerapan metode tersebut untuk analisis indeks kekeringan di daerah aliran sungai Siak diharapkan menjadi alat untuk mendeteksi kejadian kekeringan yang dapat berdampak pada kebakaran hutan dan lahan gambut. 


\section{TINJAUAN PUSTAKA}

\subsection{Kekeringan}

Kekeringan adalah kekurangan curah hujan dari biasanya atau kondisi normal. Apabila terjadi kekeringan berkepanjangan sampai mencapai satu musim atau lebih panjang akan mengakibatkan ketidakmampuan memenuhi kebutuhan air yang dicanangkan. Hal ini akan menimbulkan dampak terhadap ekonomi, sosial, dan lingkungan alam. Hujan normal akan menggambarkan kondisi yang umum terjadi dengan iklim seperti wilayah setempat. Setiap kekeringan berbeda dalam intensitas, lama, dan sebaran ruangannya (Anonim, 2003). Klasifikasi kekeringan adalah sebagai berikut (lihat Oktaviani, 2015) :

- Kekeringan Meteorologis, kekeringan ini berkaitan dengan tingkat curah hujan yang terjadi berada dibawah kondisi normalnya pada suatu musim. Perhitungan tingkat kekeringan meteorologis merupakan indikasi pertama terjadinya kondisi kekeringan.

- Kekeringan Pertanian, kekeringan ini menghubungkan berbagai karakteristik meteorology dengan dampak pertanian. Kondisi kurang hujan dikaitkan dengan evapotranspirasi aktual dan potensi, air tanah yang menyusut, karakteristik dari tanaman tertentu seperti tingkat pertumbuhan, dan penyusutan aliran air sungai, waduk dan air tanah. Kekeringan pertanian ini terjadi setelah gejala kekeringan meteorologi.

- Kekeringan Hidrologis, kekeringan berhubung dengan berkurangnya pasokan air permukaan dan air tanah.

Sementara itu indeks kekeringan merupakan suatu perangkat utama untuk mendeteksi, memantau, dan mengevaluasi kejadian kekeringan. Kekeringan memiliki karakter multidisiplin yang membuat tidak adanya sebuah definisi yang dapat diterima oleh semua pihak di dunia. Perlunya mengembangkan analisis indeks kekeringan, yaitu:

- Secara ilmiah diperlukan indikator untuk mendeteksi, memantau, dan mengevaluasi kejadian kekeringan.

- Perkembangan teknologi pengambilan data dan metodologi analisa juga memberikan arah baru pengembangan indeks kekeringan.

- Kebutuhan untuk pelaksanaan alokasi air di lapangan.

Penentuan analisa indeks kekeringan bertujuan untuk:

- Mengevaluasi kecenderungan klimatologi menuju keadaan kering atau tingkat kekeringan suatu daerah.

- Memperkirakan kebutuhan air irigasi untuk pertanian dan perkebunan pada suatu luasan area tertentu.

- Mengevaluasi kekeringan pada suatu tempat secara lokal.

- Melaporkan secara berkala perkembangan analisa indek kekeringan secara regional.

\subsection{Metode Thornthwaite Mather}

Metode ini menekankan pentingnya faktor curah hujan $(P)$ dan evapotranspirasi potensial $(P E)$ sebagai faktor iklim. Selain itu juga dibutuhkan parameter kelengasan tanah dan jenis vegetasi (Kafindo, 2015). Imbangan antara hujan dan evapotranspirasi potensial ( $P$ dan $P E$ ) 
menunjukkan keadaan berlangsungnya periode bulan kering maupun periode bulan basah. Periode kering terjadi bila $P<P E$ dan menimbulkan keadaan kekurangan air, sehingga diperlukan tambahan kadar air tersimpan dalam tanah yang berupa kelengasan. Penggunaan kelengasan (storage $=S T$ ) oleh tanaman menyebabkan terjadinya perubahan kelengasan dalam tanah (ST), sehingga kekurangan air hujan yang terus-menerus menyebabkan kelembaban dalam tanah semakin menurun. Awal periode basah berikutnya $(P>P E)$, kelembaban dalam tanah akan terisi kembali dan terjernihkan hingga mencapai kapasitas lapang ( $S T o$ ) jika jumlah kelebihan air hujan mencukupi. Sebaliknya jika jumlah keseluruhan kelebihan air hujan pada periode basah tersebut lebih kecil dari pada kapasitas lapang, STotidak akan tercapai. Besarnya $S T$ To ditentukan oleh kapasitas tanah menahan air (water hoding capacity) yaitu faktor tanah dan vegetasi (Jauhari, 2015).

Pada periode bulan basah evapotranspirasi aktual diasumsikan sama dengan nilai evapotranspirasi potensial $(P E=E A)$, tetapi pada periode bulan kering evapotranspirasi aktual selalu lebih kecil dari pada evapotranspirasi potensial $(E A<P E)$. Saat demikian nilai evapotranspirasi aktual sama dengan besarnya hujan ditambah jumlah kelembaban yang digunakan oleh tanaman $(E A=P+S T)$. Periode bulan basah, biasanya jumlah curah hujan masih lebih besar dari pada yang teruapkan atau yang digunakan tanaman, sehingga terjadi kelebihan lengas. Sebaliknya periode bulan kering, jumlah air hujan tidak mencukupi kebutuhan air yang digunakan oleh tanaman, sehingga terjadi kekurangan lengas. Hubungan antara kekurangan kelengasan tanah dan evapotranspirasi potensial ( $P E)$ menghasilkan indeks kekeringan (Ia).

Tabel 1. Indeks Kekeringan Thornthwaite Matter

\begin{tabular}{ll}
\hline Indeks kekeringan $(\%)$ & Tingkat Kekeringan \\
\hline$<16,77$ & Ringan \\
\hline $16,77-33,33$ & Sedang \\
\hline$>33,33$ & Berat \\
\hline
\end{tabular}

\section{HASIL DAN PEMBAHASAN}

Data-data yang dipergunakan dalam penelitian ini diperoleh dari Balai Wilayah Sungai Sumatera (BWSS) III, yaitu sebagai berikut:

- Data curah hujan harian DAS Siak selama pengamatan tahun 2006 sampai dengan tahun 2015 dengan empat stasiun hujan.

Tabel 2. Stasiun Hujan DAS Siak

\begin{tabular}{ll}
\hline Stasiun Hujan & Elevasi $(\mathrm{m})$ \\
\hline Buatan & 6 \\
Kandis & 30 \\
Petapahan Baru & 40 \\
Pekanbaru & 3,5 \\
\hline
\end{tabular}

- Data klimatologi meliputi data suhu. Data klimatologi yang tersedia di lokasi studi adalah Stasiun Klimatologi Buatan selama pengamatan tahun 2006 sampai dengan tahun 2015.

- Peta penggunaan lahan dan peta tekstur tanah di daerah Aliran sungai Siak (lihat Gambar 2 dan Gambar 3. 


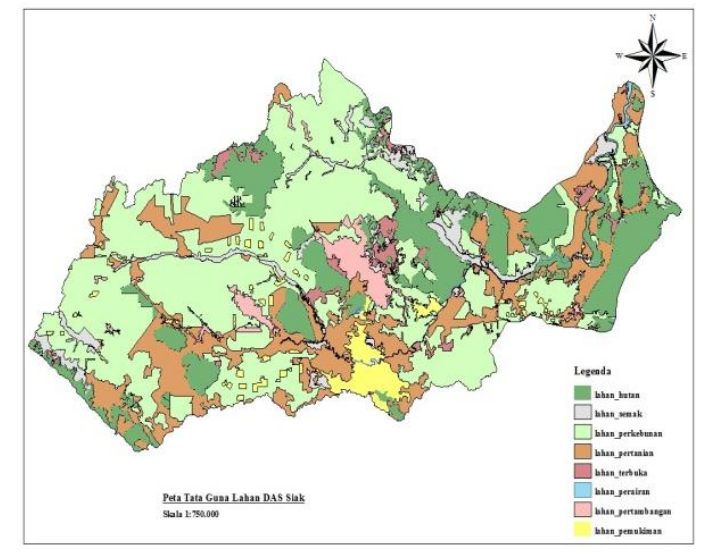

Gambar 2. Peta Penggunaan Lahan

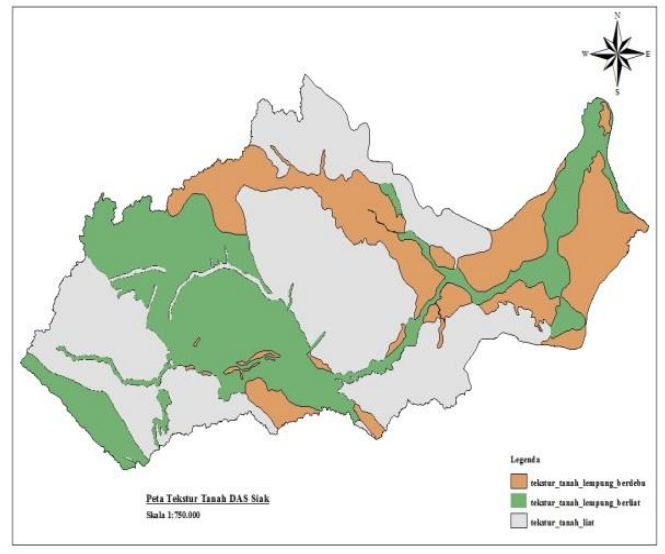

Gambar 3. Peta Tekstur Tanah

Stasiun Kandis, Petapahan Baru dan Pekanbaru tidak memiliki data suhu udara, maka digunakan stasiun Buatan sebagai referensi, dan sebagai pendekatan nilai suhu udara digunakan cara Mock (Mujtahiddin, 2014) :

$\Delta T=0,006\left(Z_{1}-Z_{2}\right)$

$T_{2}=T_{1}+\Delta T$

Dimana, $\Delta T=$ Selisih temperatur udara masing-masing stasiun $\left({ }^{\circ} \mathrm{C}\right), Z_{1}=$ Ketinggian stasiun acuan (m), $Z_{2}=$ Ketinggian curah hujan yang diperhitungkan (m), $T_{2}=$ Suhu udara bulan kei yang dianalisis $\left({ }^{\circ} \mathrm{C}\right), T_{I}=$ Suhu udara acuan bulan ke-i $\left({ }^{\circ} \mathrm{C}\right)$.

Dalam metode Thornthwaite Mather, analisis evapotranspirasi potensial dihitung dengan menggunakan persamaan sebagai berikut :

- Menghitung indeks panas ( $i$ ) dengan rumus : $i=(T / 5)^{1,514}$

- Menghitung jumlah indeks panas dalam setahun (I) dengan rumus : $I=\sum i$

- Menghitung variabel $a$ dengan rumus :

$a=\left(0,675 \cdot 10^{-6} \cdot I^{3}\right)-\left(0,77 \cdot 10^{-4} \cdot I^{2}\right)+0,01792 \cdot I+0,49239$

- Menghitung evapotranspirasi potensial belum terkoreksi :

$P e x=16(10 T / I)^{a}$

- Menghitung evapotranspirasi potensial ( $P E)$ terkoreksi :

$$
P E=f . P e x
$$

Sebaran penggunaan lahan serta jenis tekstur tanah pada daerah aliran sungai Siak dapat dilihat pada Tabel 3 dan Tabel 4. Luas pengaruh dari masing-masing stasiun hujan menggunakan pendekatan metode poligon Thiessen sebagaimana Gambar 4. 
Tabel 3. Tata Guna Lahan

\begin{tabular}{ll}
\hline Tata Guna Lahan & Area $\left(\mathrm{km}^{2}\right)$ \\
\hline Hutan & 2200,05 \\
Semak & 584,87 \\
Perkebunan & 5276,84 \\
Pertanian & 2253,08 \\
Terbuka & 286,63 \\
Perairan & 66,72 \\
Pertambangan & 330,77 \\
Pemukiman & 481,84 \\
\hline Jumlah & 11480,80 \\
\hline
\end{tabular}

Tabel 4. Tekstur Tanah

\begin{tabular}{ll}
\hline Tekstur Tanah & Area $\left(\mathrm{km}^{2}\right)$ \\
\hline Lempung Berdebu & 2565,40 \\
Lempung Berliat & 3641,21 \\
Liat & 5274,19 \\
Jumlah & 11480,80 \\
\hline
\end{tabular}

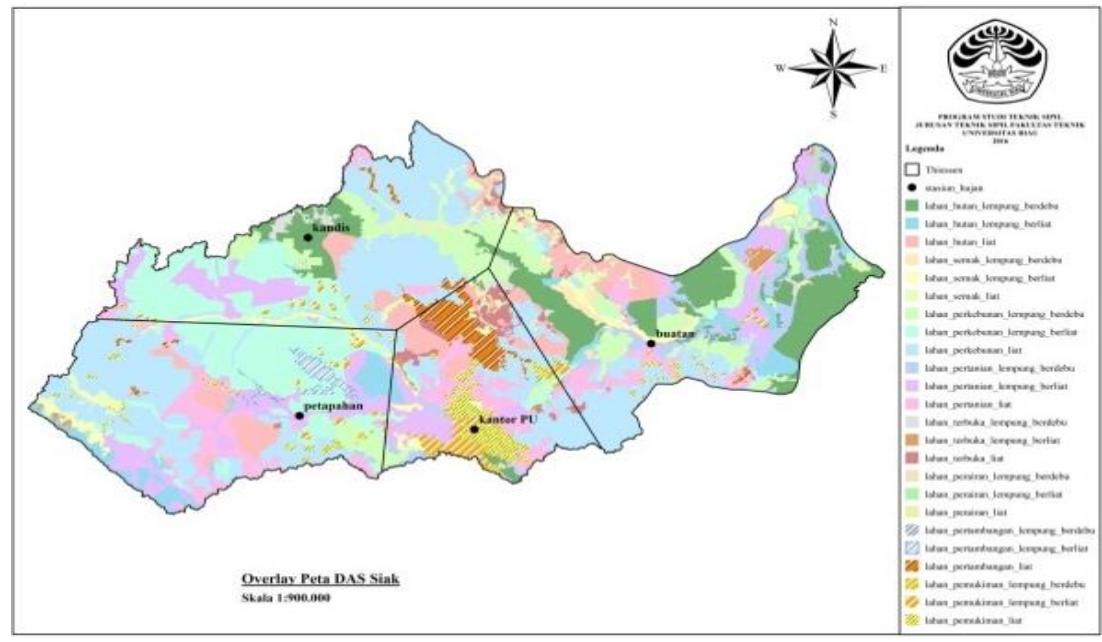

Gambar 4. Peta Poligon Thiessen

Hasil anailsis indeks kekeringan merupakan hasil keseimbangan air (water balance) antara data curah hujan $(P)$, evapotranspirasi potensial $(P E)$ sebagai faktor iklim hasil analisis, dan indeks kekeringan (Ia). Hasil analisis secara sederhana ditampilkan dalam bentuk gambar yang menunjukkan hubungan ketiga variabel tersebut (lihat Gambar 5).

Berdasarkan Gambar 5, diperoleh kesimpulan terdapat hubungan antara curah hujan $(P)$, evapotranspirasi potensial ( $P E$ ) dan indeks kekeringan (Ia). Jika $P P E$ (periode bulan basah) maka tidak terjadi kekeringan ( $I a=0$ ), sebaliknya jika $P<P E$ (periode bulan kering) maka terjadi kekeringan. Pada periode bulan kering $P<P E$ jumlah air hujan tidak mencukupi kebutuhan air yang digunakan oleh tanaman, sehingga terjadi kekurangan kelengasan tanah (moisture deficiency). Hubungan antara kekurangan kelengasan tanah dan evapotranspirasi potensial ( $P E)$ menghasilkan indeks kekeringan (Ia). 


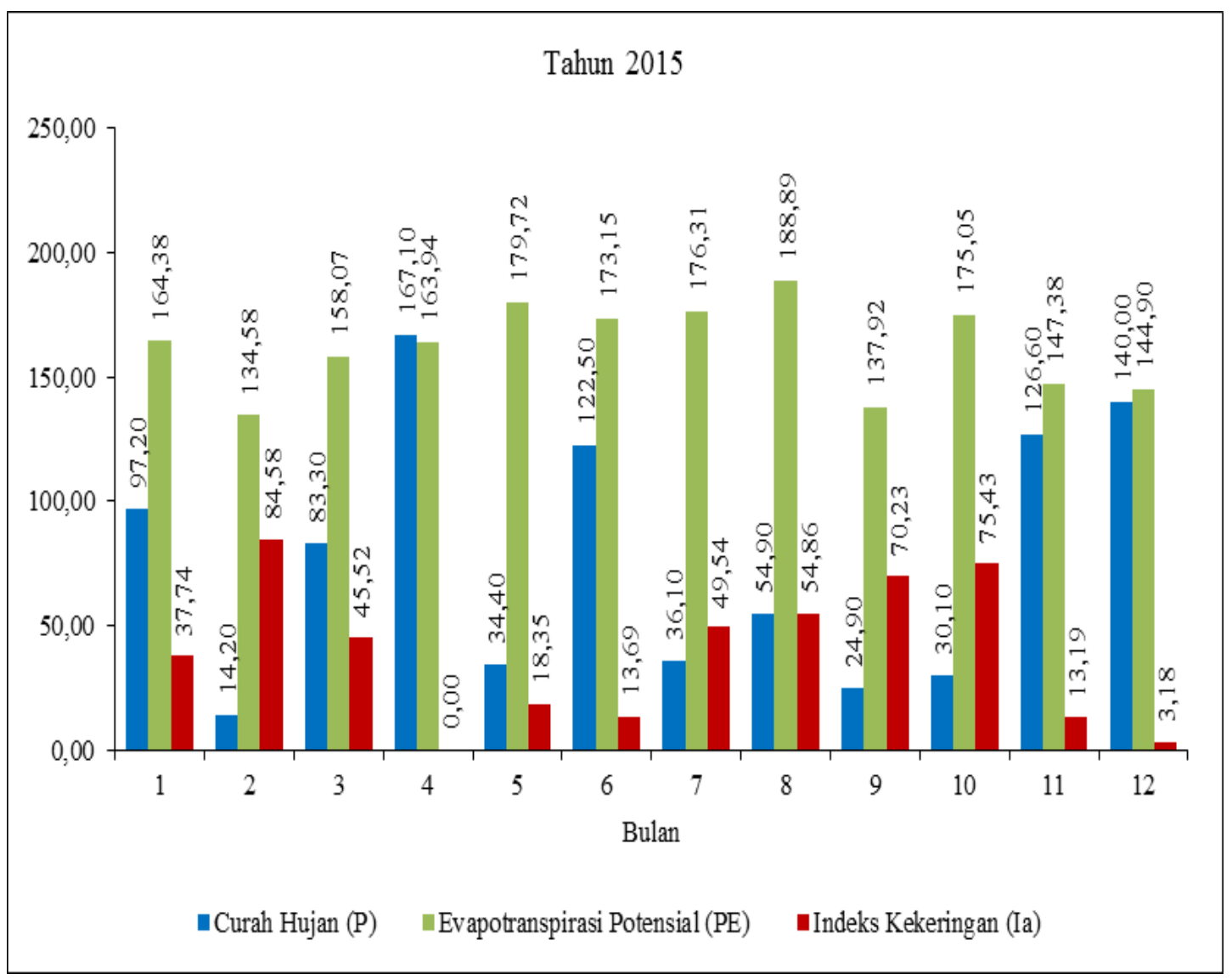

Gambar 5. Perbandinga Nilai Hujan, Evapotrasnpirasi dan Indeks Kekeringan

Analisis spasial dilakukan setelah semua indeks kekeringan di masing-masing stasiun dihitung. Berdasarkan analisis variabilitas iklim, diperoleh hasil bahwa DAS Siak mengalami perubahan iklim, yaitu ditandai dengan meningkatnya suhu udara yang diikuti dengan menurunnya curah hujan. Dimana suhu udara pada DAS Siak tahun 2006 sampai dengan tahun 2015 mengalami peningkatan sebesar $0,14{ }^{\circ} \mathrm{C}$ per-tahun. Kondisi perubahan iklim ini menyebabkan bertambahnya periode El Nino dimana bulan-bulan kering berlangsung dalam durasi yang lama. Kondisi ini memberikan efek pada tingkat intensitas dan frekuensi curah hujan yang semakin berkurang (menurun) bahkan pada periode bulan-bulan basah seperti bulan September, Oktober, Nopember masih juga terjadi kekeringan tingkat berat.

Penggambaran peta spasial sebaran kekeringan merupakan hasil analisis indeks kekeringan guna mengetahui lebih jelas durasi periode bulan kering yang menyebabkan terjadinya kekeringan. Penggambaran peta spasial sebaran kekeringan ini didasarkan pada peta polygon thiessen semua stasiun hujan. Tingkat kekeringan yang terjadi ditampilkan dalam tiga warna dengan dasar pemilihan warna sesuai peta indeks resiko bencana kekeringan Provinsi Riau yang dikeluarkan oleh Badan Nasional Penanggulangan Bencana (BNBP), yaitu, warna hijau menunjukan kekeringan tingkat ringan $(<16,77 \%)$, warna kuning menunjukan kekeringan tingkat sedang (16,77\% - 33,33\%), dan warna merah menunjukan kekeringan tingkat berat ( $>33,33 \%)$. Peta spasial sebaran kekeringan tahun 2015 ditunjukkan sebagimana Gambar 6. Jika peta spaisal sebaran kekeringan dengan bencana asap di tahun 2015 maka hasilnya menunjukkan adanya hubungan yang kuat dimana kejadian bencana asap terjadi pada bulan Juli hingga September tahun 2015. 


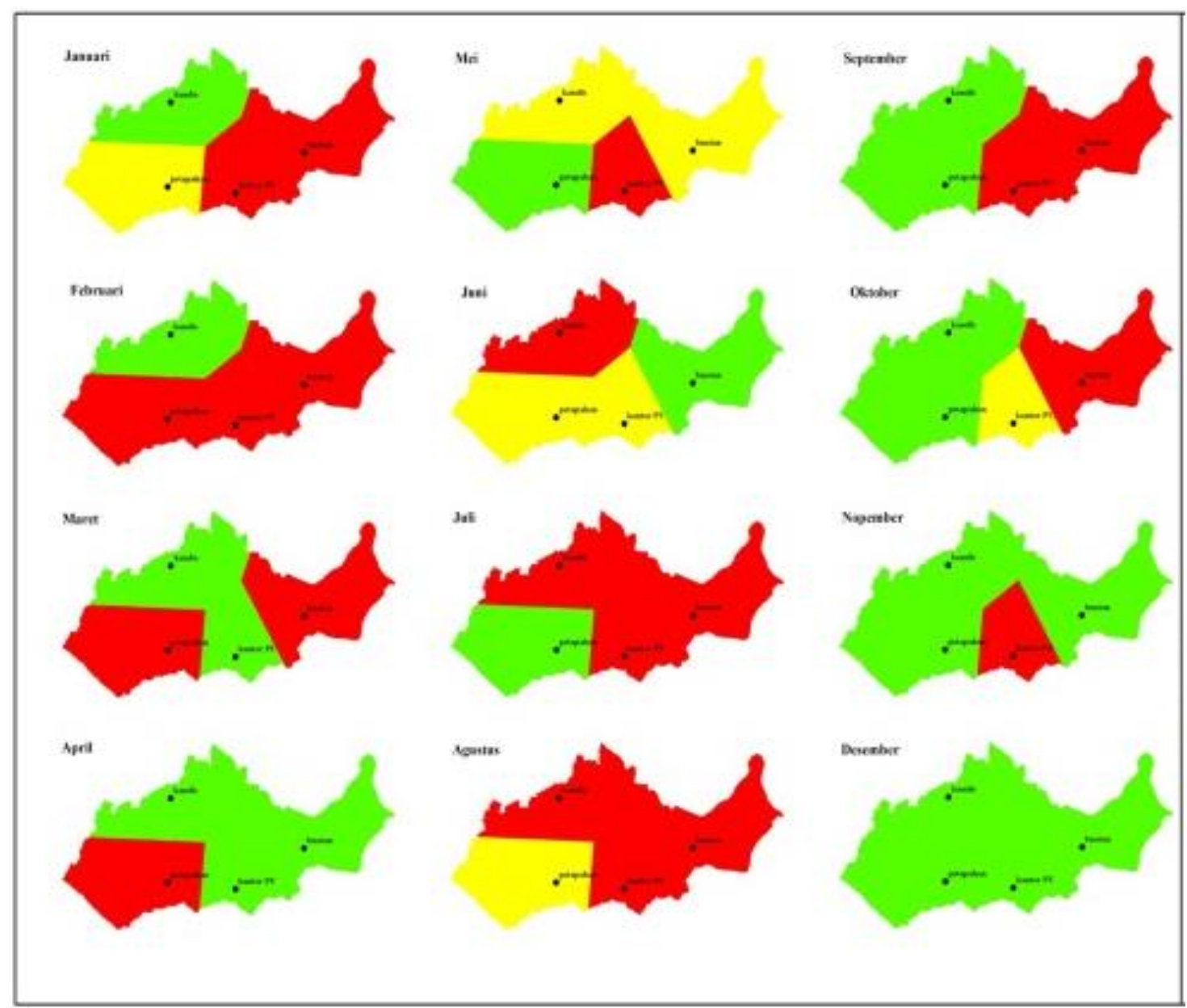

Gambar 6. Peta Sebaran Kekeringan DAS Siak Tahun 2015

\section{KESIMPULAN}

1. Kekeringan terbesar terjadi pada Tahun 2014 dan Tahun 2015, dimana untuk data hujan dari stasiun Kandis, Petapahan Baru dan Pekanbaru terjadi pada Tahun 2014 dengan nilai indkes berturut-turut 398,33\%, 757,17\% dan 520,77\%. Sedangkan stasiun Buatan kekeringan terbesar terjadi pada Tahun 2015 dengan nilai indeks 466,31\%.

2. Analisis juga menunjukan adanya trend perubahan suhu udara dimana setiap tahun suhu udara mengalami peningkatan $0,14{ }^{\circ} \mathrm{C}$ dan diikuti terjadinya trend perubahan curah hujan yang setiap tahun mengalami penurunan sebesar 34,57 $\mathrm{mm} / \mathrm{thn}$, hubungan kedua trend ini menyebabkan terjadinya trend peningkatan indeks kekeringan sebesar 8,61 \% per-tahun selama periode data yang digunakan dalam analisis. 


\section{DAFTAR PUSTAKA}

Badan Nasional Penenggulangan Bencana. 2016. Pedoman Umum Pengkajian Risiko Bencana. Jakarta.

Departemen Pekerjaan Umum. 2003. Permasalahan Kekeringan dan Cara Mengatasinya. Puslitbang Sumber Daya Air. Bandung.

Ersyidarfia, N., Fauzi, M., dan Sujatmoko, B. 2012. Perhitungan Indeks Kekeringan Menggunakan Teori Run pada DAS Indragiri. Thesis for Undergraduate Program. Universitas Riau, Pekanbaru (unpublished).

Jauhari, M. 2015. Penerapan Metode Thornthwaite Mather dalam Analisa Kekeringan Di DAS Dodokan Kabupaten Lombok Tengah Nusa Tenggara Barat. Thesis for Undergraduate Program. Universitas Brawijaya Fathur, Malang (unpublished).

Kafindo, A.N. 2015. Analisa Kekeringan Menggunakan Metode Thornthwaite Mather pada Sub-sub DAS Keyang Kabupaten Ponorogo. Thesis for Undergraduate Program. Universitas Brawijaya Fathur, Malang (unpublished).

Kementerian Pekerjaan Umum dan Perumahan Rakyat. 2015. Permen PUPR No. 04/PRT/M?2015 Tentang Kriteria dan Penetapan Wilayah Sungai. Jakarta.

Oktaviani, S. 2015. Analisis Kekeringan dengan Menggunakan Metode Theory Of Run Studi Kasus DAS Ciujung. Thesis for Undergraduate Program. Universitas Sultan Ageng Tirtayasa, Banten (unpublished). 